\title{
Comparison of electrocatalytic activity for glucose electrooxidation of gold nanoparticles fabricated by different methods
}

Daina Upskuvien $\dot{\mathbf{1}}^{*}$,

Aldona Balčiūnaitè ${ }^{1}$,

Jūratė Vaičiūniené ${ }^{1}$,

Algirdas Selskis',

Rimantas Vaitkus ${ }^{1,2}$,

Loreta Tamašauskaitė-Tamašiūnaite் ${ }^{1}$,

Eugenijus Norkus ${ }^{1}$

${ }^{1}$ Department of Catalysis,

Center for Physical Sciences and Technology,

Sauletekio Ave. 3, 10257 Vilnius, Lithuania

${ }^{2}$ Faculty of Chemistry and Geosciences,

Vilnius University,

Naugarduko St. 24,

03225 Vilnius, Lithuania
In this study, the gold nanoparticles (AuNPs) without carbon support were prepared using the well-known citrate reduction method. The carbon supported AuNPs nanocomposites were fabricated by two different approaches: chemical adsorption of AuNPs from the prepared citrate stabilized AuNP colloidal solution on the carbon powder surface and one-pot microwave-assisted synthesis. The nanocomposites were characterized using scanning electron microscopy (SEM) and inductively coupled plasma optical emission spectroscopy (ICP-OES). The electrocatalytic activity of the prepared catalysts was evaluated for the electrooxidation of glucose in an alkaline media using cyclic voltammetry.

The highest electrocatalytic activity was observed for the catalyst of carbon supported Au nanoparticles prepared by microwave-assisted synthesis, followed by the catalyst of carbon supported Au nanoparticles prepared by means of the adsorption method, whereas the pure Au nanoparticles without carbon support exhibited the lowest electrocatalytic properties for glucose electrooxidation.

Keywords: gold, nanoparticles, microwave synthesis, glucose, electrooxidation

\section{INTRODUCTION}

Since the ancient times, colloidal gold or the gold nanoparticles (AuNPs) have been used especially by the Romans in the field of glass staining [1]. Moreover, the gold nanoparticles have attracted a considerable attention for many years in chemistry, biology and medicine due to their oxide-free surface, bioconjugation properties, good biocompatibility, and unique optical properties [2]. They are the one of the well-studied building blocks in nanotechnology because of their ease of prepara-

*Corresponding author. Email: daina.upskuviene@gmail.com tion, high stability, their shape and size-dependent catalytic activity. Furthermore, AuNPs have been extensively used in various applications such as catalysis [3-5], electronics [6], nanobiotechnology [⿰], biomedicine [2, 8, 9] and sensors [2, 10, 11].

The catalytic properties of $\mathrm{Au}$ nanoparticles for the oxidation of glucose should be understood due to the interest not only in the development of glucose sensors for monitoring diabetes and food industry use, but also for the development of biological direct glucose fuel cells (DGFCs) [12-14]. Glucose is an easily available, cheap and non-toxic biofuel. It is produced in abundance from both naturally occurring plants and industrial processes. 
Theoretically, glucose can be completely oxidized to carbon dioxide and water, releasing 24 electrons per molecule of glucose [15]. The corresponding reaction is given in Eq. (1):

$$
\mathrm{C}_{6} \mathrm{H}_{12} \mathrm{O}_{6}+24 \mathrm{OH}^{-} \rightarrow 6 \mathrm{CO}_{2}+18 \mathrm{H}_{2} \mathrm{O}+24 \mathrm{e}^{-}
$$

However, the completion of reaction is rare and unlikely. The transfer of two electrons per molecule of glucose has not yet been realized. Up to date, only partial oxidation of glucose has been achieved, furthermore, the initial step involves breaking a $\mathrm{C}-\mathrm{H}$ bond producing gluconic acid. Electrooxidation of glucose to gluconic acid yields only two electrons per molecule of glucose. The corresponding reaction is given in Eq. (2) [13]:

$$
\mathrm{C}_{6} \mathrm{H}_{12} \mathrm{O}_{6}+2 \mathrm{OH}^{-} \rightarrow \mathrm{C}_{6} \mathrm{H}_{12} \mathrm{O}_{7}+\mathrm{H}_{2} \mathrm{O}+2 \mathrm{e}^{-} \text {. }
$$

The electrocatalytic oxidation of glucose has been studied extensively [16-29]. It has been determined that gold shows an excellent analytical performance for the direct oxidation of glucose. Gold is an attractive metal for the oxidation of glucose, because its oxidation potential in both alkaline and neutral solutions is more negative compared to that of the other metals [16, 18]. The formation of catalytically active sites $\mathrm{Au}-\mathrm{OH}_{\mathrm{ads}}$ is the most important step for the glucose oxidation reaction (GOR). On the other hand, the generation of an oxide precursor in the potential region prior to gold oxide formation is an important characteristic of Au electrodes, which plays a key role in enhancing the catalytic activity of $\mathrm{Au}$ in alkaline solutions [15, 16]. It has been found that nanoporous gold exhibited a much better electrocatalytic activity for GOR in neutral and alkaline solutions as compared to bulk gold due to both its rough surface morphology and the availability for $\mathrm{OH}^{-}$adsorption [15]. The good electrocatalytic activity of AuNPs supported on carbon or graphene for GOR was ascribed to the synergistic effect of carbon, graphene or reduced graphene oxide and AuNPs [15, 25, 28]. The high density and well-distributed AuNPs on the surface of carbon or graphene would induce more active sites for the catalytic redox reaction.

Various methods of AuNPs synthesis using the chemical, irradiation, sonochemical or photo- chemical methods as well as their application in different research areas have been reported and reviewed [30-39]. The most common chemical route for the preparation of AuNPs is chemical reduction of a suitable gold precursor, for example, $\mathrm{HAuCl}_{4}$, with the reducing agents, such as organic acids, sugars, aldehydes, alcohols, block-copolymers and other strong reducing agents - sodium borohydride and hydrazine [40-44]. Among the conventional methods of chemical synthesis of colloidal gold, the Turkevich procedure is highly utilized due to the simplicity and ease of synthesis, controllable size and stability of colloidal nanoparticles [30-39, 45-48]. In this study, the AuNPs were prepared using the citrate reduction method. For fabrication of the carbon supported AuNPs nanocomposites two different approaches were used: chemical adsorption of AuNPs from the prepared citrate stabilized AuNP colloidal solution on the carbon powder surface and one-pot microwave-assisted synthesis. The nanocomposites were characterized using scanning electron microscopy (SEM) and inductively coupled plasma optical emission spectroscopy (ICP-OES). The electrocatalytic properties of the prepared catalysts were evaluated for the oxidation of glucose in an alkaline media using cyclic voltammetry.

\section{EXPERIMENTAL}

\section{Chemicals}

$\mathrm{HAuCl}_{4} \cdot 3 \mathrm{H}_{2} \mathrm{O}$ (gold(III) chloride trihydrate, 99.9\%), $\mathrm{Na}_{3} \mathrm{C}_{6} \mathrm{H}_{5} \mathrm{O}_{7} \cdot 2 \mathrm{H}_{2} \mathrm{O}$ (trisodium citrate dihydrate, $99.9 \%), \mathrm{C}_{6} \mathrm{H}_{12} \mathrm{O}_{6} \cdot \mathrm{H}_{2} \mathrm{O}(\mathrm{D}-(+)$-glucose, 99.5\%), graphite powder (99.9995\%) were purchased from Alfa-Aesar and Sigma-Aldrich suppliers and used as received without further purification. $\mathrm{H}_{2} \mathrm{SO}_{4}$ (96\%), $\mathrm{NaOH}(98.8 \%)$ and ethanol (96\%) were purchased from Chempur Company. Nafion (5 wt.\%, D521, 1100 EW) was purchased from Ion Power Inc. Ultra-pure water with the resistivity of $18.2 \mathrm{M} \Omega \mathrm{cm}^{-1}$ was used to prepare all the solutions. All the reagents used were of analytical grade.

\section{Fabrication of catalysts}

AuNPs were prepared by the citrate reduction method. $\mathrm{HAuCl}_{4}$ and trisodium citrate were used as a gold precursor and a reducing agent, 
respectively. Briefly, $2 \mathrm{ml}$ of $0.01 \mathrm{M} \mathrm{HAuCl}_{4}$ was added into $17 \mathrm{ml}$ of deionized water and boiled. Then, $1 \mathrm{ml}$ of $0.1 \mathrm{M}$ trisodium citrate was added into the gold precursor solution at $90^{\circ} \mathrm{C}$ temperature. The solution was stirred at the same temperature until its colour changed from light blue via pink to cherry red. Additionally, the solution was boiled for $15 \mathrm{~min}$. After that, the solution was cooled down to room temperature. The obtained citrate stabilized AuNP colloidal solution was used for the deposition of AuNPs on the glassy carbon electrode. The prepared catalyst was termed as AuNPs.

AuNPs supported carbon powder catalysts were prepared by two different approaches: chemical adsorption of AuNPs from the prepared citrate stabilized AuNP colloidal solution on the carbon powder surface and one-pot microwave-assisted synthesis. In the first case, $100 \mathrm{mg}$ of carbon powder was added into the prepared citrate stabilized AuNP colloidal solution $(20 \mathrm{ml})$ at room temperature and stirred for $1 \mathrm{~h}$. The obtained precipitates were filtered, washed with ultra-pure water and dried in a vacuum oven at $80^{\circ} \mathrm{C}$ temperature for $2 \mathrm{~h}$. The prepared catalyst was termed as AuNPs/ $\mathrm{C}_{\mathrm{ads}}$. In another case, the reaction mixture $(20 \mathrm{ml})$ containing $100 \mathrm{mg}$ of carbon powder, $2 \mathrm{ml}$ of $0.01 \mathrm{M}$ $\mathrm{HAuCl}_{4}$ and $1 \mathrm{ml}$ of $0.1 \mathrm{M}$ trisodium citrate was thoroughly mixed and put into a microwave reactor Monowave 300 (Anton Paar). The synthesis of the AuNPs supported carbon powder was carried out at $90^{\circ} \mathrm{C}$ temperature for $7 \mathrm{~min}$. After the preparation, the synthesized catalyst was washed with ultra-pure water, then filtered and dried in a vacuum oven at $80^{\circ} \mathrm{C}$ temperature for $2 \mathrm{~h}$. The prepared catalyst was termed as AuNPs/ $\mathrm{C}_{\mathrm{MW}}$

\section{Characterization of catalysts}

The surface morphology and composition of the prepared catalysts were examined using a SEM/ FIB workstation HeliosNanolab 650 with an energy dispersive X-ray (EDX) spectrometer INCA Energy 350 X-Max 20.

The Au metal loading in the prepared catalysts was estimated using an ICP optical emission spectrometer Optima 7000 DV (Perkin Elmer).

\section{Electrochemical measurements}

The measurements of glucose electrooxidation were performed with a Zennium electrochemi- cal workstation using a conventional three-electrode cell. The working electrode was a thin layer of the prepared AuNPs, AuNPs/C ads and AuNPs/ $\mathrm{C}_{\mathrm{MW}}$ catalysts cast on a glassy carbon (GC) electrode with a geometric area of $0.07 \mathrm{~cm}^{2}$. A Pt wire was used as a counter electrode and an $\mathrm{Ag} / \mathrm{AgCl} /$ $\mathrm{KCl}(3 \mathrm{M} \mathrm{KCl})$ electrode was used as a reference. The layers of the AuNPs/ $\mathrm{C}_{\text {ads }}$ and AuNPs/ $\mathrm{C}_{\mathrm{MW}}$ catalysts were obtained according to the following steps: at first, $10 \mathrm{mg}$ of the prepared catalysts were dispersed ultrasonically for $1 \mathrm{~h}$ in a solution containing $25 \mu \mathrm{l} \mathrm{Nafion}$ and $75 \mu \mathrm{l} \mathrm{H}_{2} \mathrm{O}$ to produce a homogeneous slurry. Then, $5 \mu \mathrm{l}$ of the prepared suspension mixture was pipetted onto the polished surface of the glassy carbon electrode and dried in a vacuum oven at $80^{\circ} \mathrm{C}$ for $2 \mathrm{~h}$. In the case of the AuNPs catalyst, $5 \mu$ of the citrate stabilized AuNP colloidal solution was pipetted onto the glassy carbon electrode and dried in the vacuum oven at $80^{\circ} \mathrm{C}$ temperature for $2 \mathrm{~h}$.

Before each measurement, the AuNPs/GC, AuNPs/ $\mathrm{C}_{\text {ads }} / \mathrm{GC}$ and AuNPs/ $\mathrm{C}_{\mathrm{Mw}} / \mathrm{GC}$ electrodes were activated and stabilized in a deaerated $0.5 \mathrm{M}$ $\mathrm{H}_{2} \mathrm{SO}_{4}$ solution at a scan rate of $100 \mathrm{mV} \mathrm{s}^{-1}$ between 0.1 and $1.6 \mathrm{~V}$ until stable cyclic voltammograms (CVs) were observed. The electrode potential was quoted versus the standard hydrogen electrode (SHE). The electrochemically active surface areas (ESAs) of AuNPs in the catalysts were determined by recording $\mathrm{CVs}$ in the deaerated $0.5 \mathrm{M} \mathrm{H}_{2} \mathrm{SO}_{4}$ solution at a scan rate of $100 \mathrm{mV} \mathrm{s}^{-1}$ and calculating the charge under the Au surface oxide reduction peak $(\mathrm{Q})$ in the CVs according to Eq. (3):

$$
\operatorname{ESA}\left(\mathrm{cm}^{2}\right)=\mathrm{Q}(\mu \mathrm{C}) / 400\left(\mu \mathrm{C} \mathrm{\textrm {cm } ^ { - 2 } ) .}\right.
$$

Here $400 \mu \mathrm{C} \mathrm{cm}^{-2}$ is the charge required for the reduction of the Au oxide monolayer [49]. ESA values expressed in terms of $\mathrm{m}^{2} \mathrm{~g}^{-1}$ were calculated according to Eq. (4):

$$
\operatorname{ESA}\left(\mathrm{m}^{2} \mathrm{~g}^{-1}\right)=\mathrm{Q} / m \times 400 .
$$

Here $m$ represents the loading amount of $\mathrm{Au}$ in the electrode (mg).

Then, CVs were recorded on the AuNPs/ GC, AuNPs/C $\mathrm{C}_{\mathrm{ads}} / \mathrm{GC}$ and AuNPs/C $\mathrm{Mw} / \mathrm{GC}$ in a background $0.1 \mathrm{M} \mathrm{NaOH}$ solution and that containing $0.1 \mathrm{M}$ glucose at a scan rate of $50 \mathrm{mV} \mathrm{s}^{-1}$ between -0.7 and $0.7 \mathrm{~V}$ at $25^{\circ} \mathrm{C}$ temperature. All 
solutions were deaerated by argon (Ar) for $15 \mathrm{~min}$ prior to measurements. The presented current density values were normalized with respect to the geometric area of catalysts.

\section{RESULTS AND DISCUSSION}

The electrocatalytic oxidation of glucose was investigated on the pure AuNPs and AuNPs supported carbon catalysts. The AuNPs were obtained from the citrate-stabilized AuNPs colloidal solution. AuNPs supported carbon catalysts were prepared by two different approaches: chemical adsorption of AuNPs from the prepared citratestabilized AuNP colloidal solution on the carbon powder surface and one-pot microwave-assisted synthesis. The morphology and size of Au NPs were characterized using scanning electron microscopy. Figure 1 shows the SEM images for the AuNPs (a, a'), AuNPs/C ${ }_{\text {ads }}\left(b, b^{\prime}\right)$ and AuNPs/ $\mathrm{C}_{\mathrm{MW}}\left(\mathrm{c}, \mathrm{c}^{\prime}\right)$ catalysts under different magnification. The SEM image of Au nanoparticles obtained from
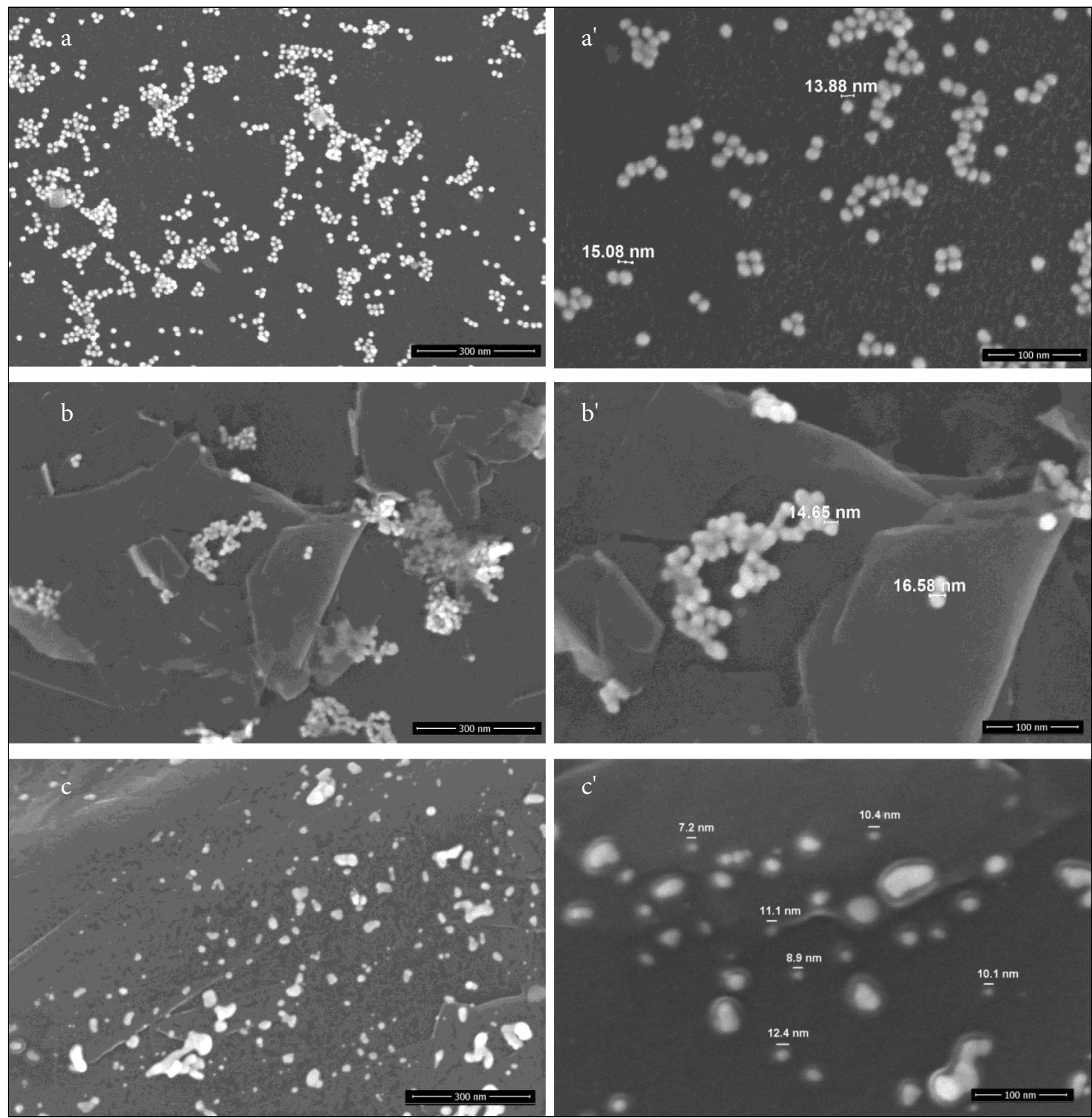

Fig. 1. SEM images of AuNPs $\left(a, a^{\prime}\right), \operatorname{AuNPs} / C_{a d s}\left(b, b^{\prime}\right)$ and $A u N P s / C_{M W}\left(c, c^{\prime}\right)$ under different magnification 
the citrate-stabilized AuNP colloidal solution (Fig. 1 1a, a') shows that the deposited Au nanoparticles were spherical in shape and homogeneously distributed. The size of the AuNPs was found to be ca. 14-15 nm (Fig. 1 a, a'). When the carbon supported AuNPs catalyst was prepared by chemical adsorption from the citrate-stabilized AuNPs colloidal solution (AuNPs/ $\mathrm{C}_{\text {ads }}$ ) (Fig. 11b, b'), the $\mathrm{Au}$ nanoparticles sized of approximately 15$17 \mathrm{~nm}$ were deposited on the carbon surface. In the case of the carbon supported AuNPs catalyst obtained by microwave synthesis (AuNPs/ $\mathrm{C}_{\mathrm{MW}}$ ) (Fig. 11c, c'), the smaller AuNPs in size of approximately 7-12 $\mathrm{nm}$ were deposited on the carbon surface. The use of microwave synthesis for the preparation of the carbon supported AuNPs catalysts results in the obtaining smaller Au NPs as compared with those obtained from the citratestabilized AuNPs colloidal solution by adsorption. It should be noted that the use of rapid irradiation heating, which is eco-friendly and energy preserving, allows not only to shorten the reaction duration in minutes instead of hours, but also to obtain smaller Au nanoparticles due to the faster kinetics of crystallization and nucleation. Although the smaller Au NPs were obtained using microwave synthesis, negligible agglomeration of $\mathrm{Au}$ NPs is seen (Fig. 1 1 c, c').

The results of ICP-OES analysis of the prepared catalysts show that the AuNPs, AuNPs/ $\mathrm{C}_{\text {ads }}$ and AuNPs/C $\mathrm{C}_{\mathrm{MW}}$ catalysts were prepared with the Au loadings corresponding to 23, 67 and $65 \mu \mathrm{g}_{\mathrm{Au}} \mathrm{cm}^{-2}$. The electrochemically active surface areas of the AuNPs, AuNPs/C ${ }_{a d s}$ and AuNPs/ $\mathrm{C}_{\mathrm{MW}}$ catalysts were determined from the CVs recorded in a deaerated $0.5 \mathrm{M} \mathrm{H}_{2} \mathrm{SO}_{4}$ solution at a scan rate of $100 \mathrm{mV} \mathrm{s}^{-1}$ (Fig. 2). The $\mathrm{CV}$ profiles of the AuNPs/GC, AuNPs/C ads $_{\text {/GC and AuNPs/ }}$ $\mathrm{C}_{\mathrm{MW}} / \mathrm{GC}$ catalysts show the usual characteristics of $\mathrm{Au}$ oxide formation and reduction. The ESAs were calculated by the charge associated with the $\mathrm{Au}$ oxide reduction $\left(400 \mu \mathrm{C} \mathrm{cm}^{-2}\right.$ for a monolayer) [49]. The summarized data are given in the Table. ESAs are $0.03,0.34$ and $0.42 \mathrm{~cm}^{2}$ for the AuNPs/GC, AuNPs/C $\mathrm{ads}_{\mathrm{ads}} / \mathrm{GC}$ and AuNPs/C $\mathrm{CW}_{\mathrm{MW}} /$ GC catalysts, respectively. The specific activity for the AuNPs/GC, AuNPs/C ads $_{\text {I }} / \mathrm{GC}$ and AuNPs/ $\mathrm{C}_{\mathrm{MW}} / \mathrm{GC}$ catalysts corresponded to $1.9,7.2$ and $9.2 \mathrm{~m}^{2} \mathrm{~g}^{-1}$. The results show that the ESAs values of the carbon supported AuNPs catalysts prepared

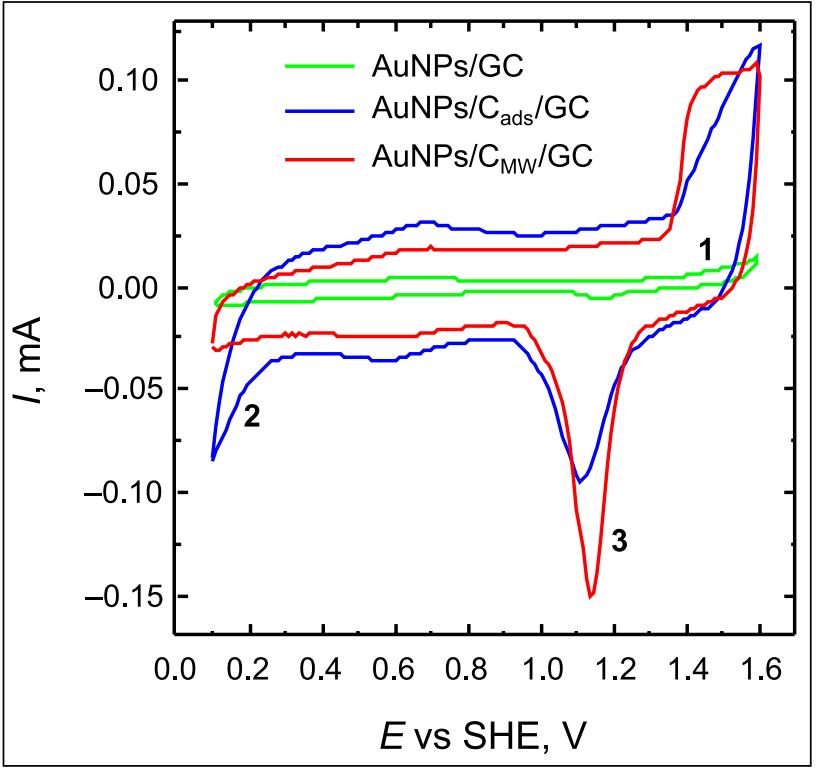

Fig. 2. CVs of the AuNPs/GC (1), AuNPs $/ \mathrm{C}_{\mathrm{ads}} / \mathrm{GC}(2)$ and $A u N P s / \mathrm{C}_{\mathrm{MW}} / \mathrm{GC}$ (3) catalysts recorded in $0.5 \mathrm{M} \mathrm{H}_{2} \mathrm{SO}_{4}$ at $100 \mathrm{mV} \mathrm{s}^{-1}$

by chemical adsorption from the citrate-stabilized AuNPs colloidal solution and microwave synthesis are approximately 11 and 14 times higher than those of the pure AuNPs catalyst.

Table. Electrochemically active areas of the Au surface of the prepared catalysts determined from $\mathrm{CVs}$ recorded in $0.5 \mathrm{M} \mathrm{H}_{2} \mathrm{SO}_{4}$ at $100 \mathrm{mV} \mathrm{s}^{-1}$. The Au loadings were estimated from ICP-OES measurements

\begin{tabular}{|c|c|c|c|}
\hline Catalyst & $\mathrm{ESA}, \mathrm{cm}^{2}$ & $E S A, m^{2} g^{-1}$ & $\begin{array}{c}\text { Au loading, } \\
\mu \mathrm{g} \mathrm{cm}^{-2}\end{array}$ \\
\hline AuNPs/GC & 0.03 & 1.9 & 23 \\
\hline AuNPs/C $\mathrm{C}_{\mathrm{ads}} / \mathrm{GC}$ & 0.34 & 7.2 & 67 \\
\hline AuNPs/C ${ }_{M w} / G C$ & 0.42 & 9.2 & 65 \\
\hline
\end{tabular}

Figure 3 shows the stabilized CVs (10th cycles) for the AuNPs/GC (a), AuNPs/C ads $_{\text {GC (b) }}$ and $A u N P s / C_{M W} / G C$ (c) catalysts recorded in a $0.1 \mathrm{M} \mathrm{NaOH}$ solution (a dashed line) and that containing $0.1 \mathrm{M}$ glucose at $25^{\circ} \mathrm{C}$ temperature at a scan rate of $50 \mathrm{mV} \mathrm{s}^{-1}$. During the forward scan, the well-defined anodic and cathodic peaks are seen in the CVs. In the case of the carbon supported AuNPs catalysts, two well-distinguished anodic peaks - one at lower potential values labelled as peak $\mathbf{A 1}$ and another one at more positive potential values labelled as peak A2 (Fig. 3 b, c) - are recorded. Notably, only one anodic peak $\mathbf{A} 2$ at more positive potential values is observed on the pure 


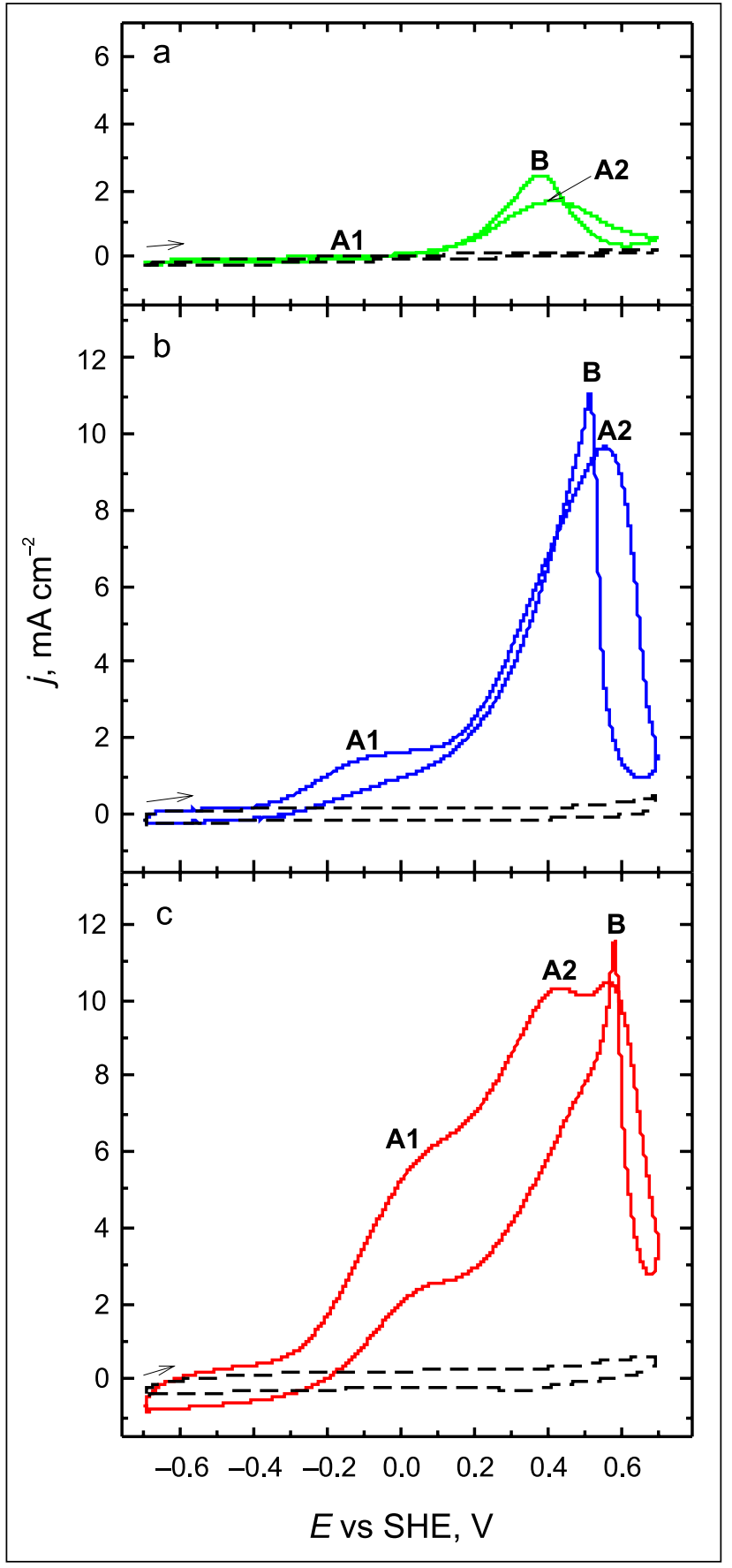

Fig. 3. CVs (10th cycles) of the AuNPs/GC (a), AuNPs/ $C_{a d s} / G C(b)$ and AuNPs $/ C_{M W} / G C(c)$ catalysts recorded in $0.1 \mathrm{M} \mathrm{NaOH}+0.1 \mathrm{M}$ glucose at $50 \mathrm{mV} \mathrm{s}^{-1}$. The dashed lines represent $\mathrm{CVs}$ of the same catalysts recorded in the background $0.1 \mathrm{M} \mathrm{NaOH}$ solution

AuNPs catalyst (Fig. 3a). It is clearly seen that the oxidation of glucose on the carbon supported AuNPs catalysts is a potential-dependent process. According to the data already reported by other authors [17, 18, 20], anodic peaks A1 and $\mathbf{A 2}$ may be related to the oxidation of glucose and the further oxidation of gluconolactone generated during the first oxidation peak A1
(Fig. 3b, c), respectively. As seen from the data presented in Fig. 3, in all cases the glucose oxidation current densities under the potential values of anodic peak A2 corresponding to the oxidation of gluconolactone are higher as compared to those recorded under peak $\mathbf{A} \mathbf{1}$ corresponding to the oxidation of glucose. However, it was reported that the formation of catalytically active sites $\mathrm{Au}-\mathrm{OH}_{\text {id }}$ is the most important step for GOR [15]. The generation of an oxide precursor in the potential region prior to gold oxide formation plays a key role in enhancing the catalytic activity of $\mathrm{Au}$ in an alkaline media. At negative potentials before the potential region of anodic peak A1, the availability of $\mathrm{Au}-\mathrm{OH}_{\mathrm{ads}}$ sites is limited for the oxidation of glucose, so the first anodic peak A1 in positive potentials may be associated with the first step of glucose oxidation, because of the greater availability of $\mathrm{Au}-\mathrm{OH}_{\mathrm{ds}}$ sites on the surface as described in Ref. [29]. Therefore, the first anodic peak $\mathbf{A 1}$ located at $0 \mathrm{~V}$ for the AuNPs/GC (a), AuNPs/C $\mathrm{ads}_{\mathrm{GC}} / \mathrm{GC}$ (b) and $\mathrm{AuNPs} / \mathrm{C}_{\mathrm{MW}} / \mathrm{GC}$ (c) catalysts is related to the adsorption of glucose on the Au surface. Moreover, the current generated for this peak is highest for the AuNPs/C $\mathrm{C}_{\mathrm{Mw}} / \mathrm{GC}$ catalyst with the value of $5.33 \mathrm{~mA} \mathrm{~cm}^{-2}$ and it is three times higher than AuNPs/ $\mathrm{C}_{\mathrm{ads}} / \mathrm{GC}\left(1.62 \mathrm{~mA} \mathrm{~cm}{ }^{-2}\right)$ and 57 times higher than AuNPs/GC (0.094 mA cm $\left.{ }^{-2}\right)$ (Fig. 3). During the second anodic peak A2 located between 0.40 and $0.56 \mathrm{~V}$, the adsorbed glucose is oxidized to gluconolactone [29] generating $9.65 \mathrm{~mA} \mathrm{~cm}^{-2}$ current for AuNPs/C ads $/ \mathrm{GC}$, whereas for AuNPs/C $\mathrm{MW}_{\mathrm{MW}} / \mathrm{GC}$ it is $10.44 \mathrm{~mA} \mathrm{~cm}^{-2}$, and for AuNPs/GC the current is $1.65 \mathrm{~mA} \mathrm{~cm}^{-2}$. Furthermore, in the backward scan, sharp cathodic peaks B observed at potentials of $0.375,0.513$ and $0.582 \mathrm{~V}$ belonging to AuNPs/GC, AuNPs/ $\mathrm{C}_{\text {ads }} / \mathrm{GC}$ and AuNPs/C $\mathrm{CW}_{\mathrm{MW}} / \mathrm{GC}$, respectively, may be attributed to the second oxidation of glucose, generating two electrons [29] (Fig. 3).

Figure 4 presents the positive-potential going scans recorded on the investigated catalysts. As evident, the current generated for anodic peak A1 at a potential value of $0 \mathrm{~V}$ is approximately 17 and 57 times higher for the AuNPs/ $\mathrm{C}_{\text {ads }} / \mathrm{GC}$ and AuNPs/ $\mathrm{C}_{\mathrm{MW}} / \mathrm{GC}$ catalysts, respectively, as compared to that of the pure AuNPs catalyst. The current densities at the electrode potential value of $0.4 \mathrm{~V}$ (peak A2) for the AuNPs/ $\mathrm{C}_{\mathrm{ads}} / \mathrm{GC}$ and 


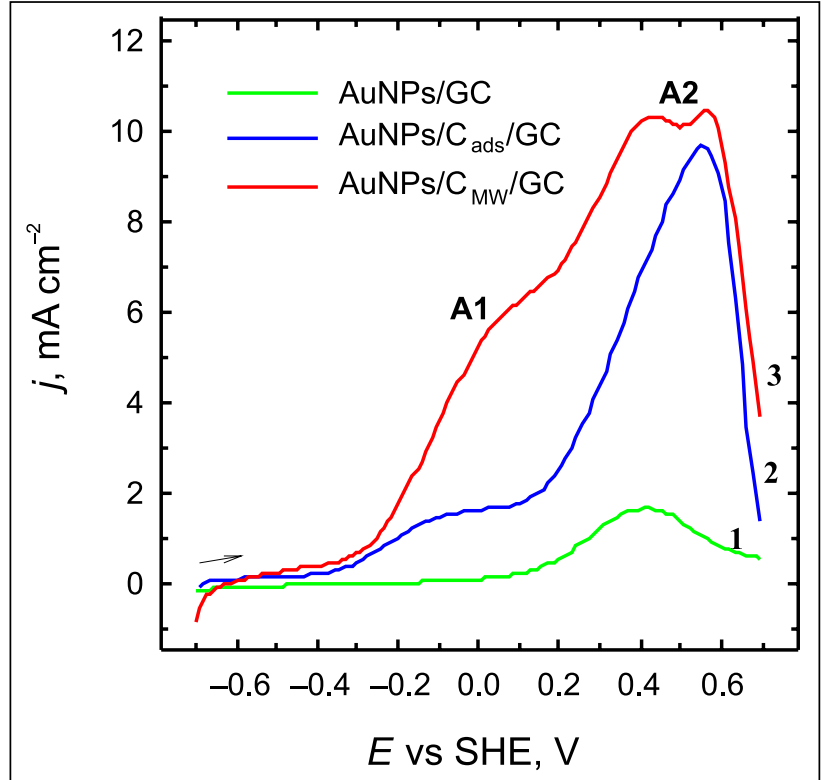

Fig. 4. Stabilized positive-potential going scans (10th cycles) of the AuNPs/GC (1), AuNPs/C $C_{\text {ads }} / G C(2)$ and $A u N P s / C_{M w} / G C(3)$ catalysts recorded in $0.1 \mathrm{M} \mathrm{NaOH}+0.1 \mathrm{M}$ glucose at $50 \mathrm{mV} \mathrm{s}^{-1}$

AuNPs/ $\mathrm{C}_{\mathrm{MW}} / \mathrm{GC}$ catalysts are approximately 4.3 and 6.2, respectively, times higher than those for the pure AuNPs/GC catalyst. Moreover, the carbon supported AuNPs catalyst prepared by microwave synthesis (AuNPs/ $\mathrm{C}_{\mathrm{Mw}} / \mathrm{GC}$ ) shows the highest electrocatalytic activity for glucose oxidation as compared with the pure AuNPs/GC catalyst and the carbon supported AuNPs catalyst prepared from the citrate-stabilized AuNPs colloidal solution by adsorption (AuNPs/C $\mathrm{ads}_{\mathrm{s}} / \mathrm{GC}$ ).

It should be noted that the oxidation of glucose on the carbon supported AuNPs catalysts occurs at more negative potential values as compared to that for pure AuNPs. These results indicate that the carbon supported AuNPs catalysts have a higher electrocatalytic activity for glucose oxidation than the pure AuNPs catalyst. Furthermore, the higher activity of the AuNPs/C catalysts for GOR is related with the synergistic effect between carbon and AuNPs and the availability for $\mathrm{OH}^{-}$adsorption.

From the practical point of view, it is of considerable attention to compare the values of mass activity (MA) of the oxidation of glucose for the catalysts studied. To represent the MA of the AuNPs and the carbon supported AuNPs catalysts, glucose oxidation current densities at the potential values of both anodic peaks A1 and A2 were normalized by the Au loadings for each catalyst (Fig. 5).

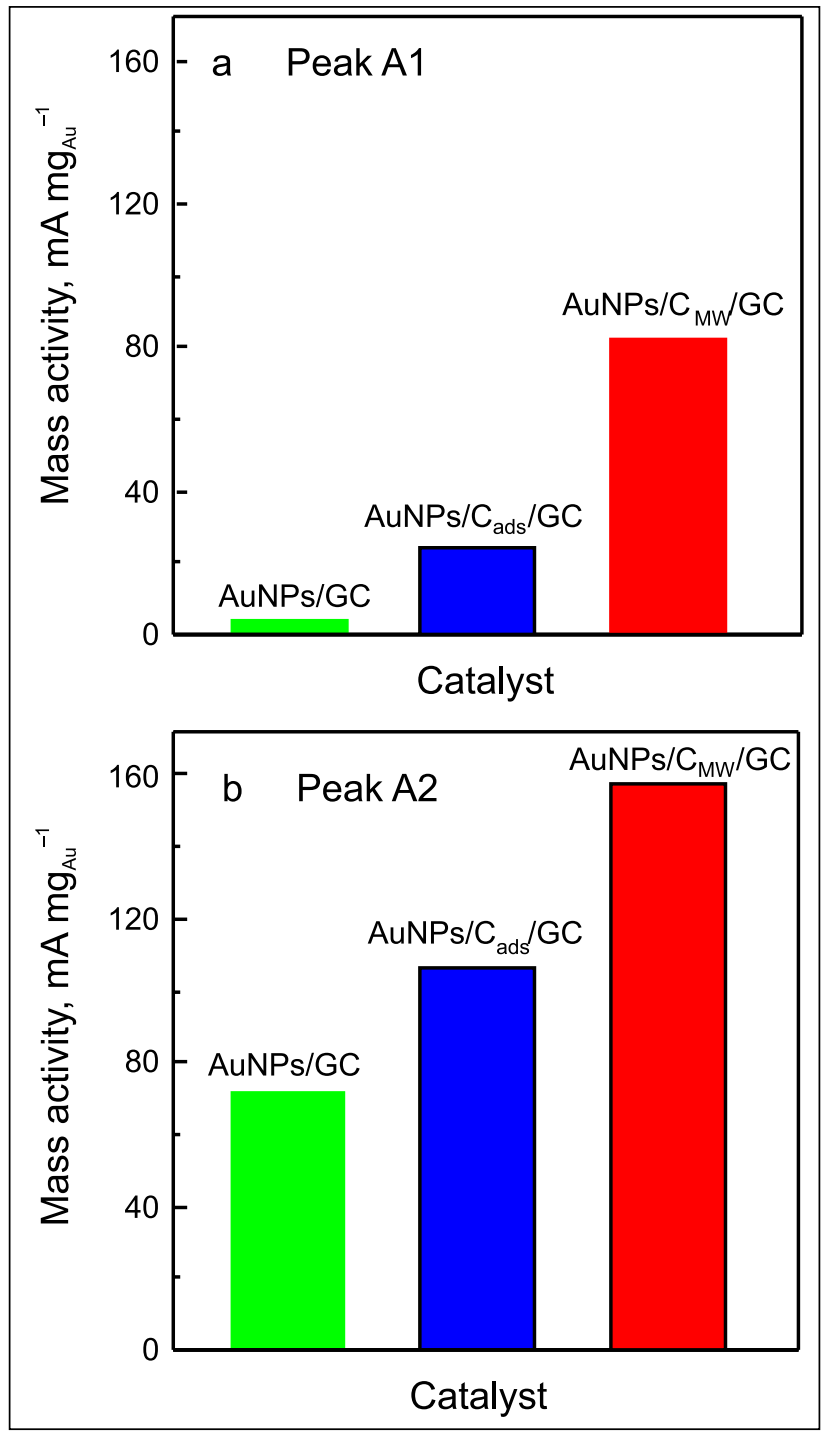

Fig. 5. Bar columns of the mass activity towards glucose oxidation for the AuNPs/GC, AuNPs $/ C_{\text {ads }} / G C$ and AuNPs $/ C_{M w} / G C$ catalysts at the potentials of anodic peak $\mathbf{A} \mathbf{1}$ (a) and $\mathbf{A 2}$ (b) recorded in $0.1 \mathrm{M}$ $\mathrm{NaOH}+0.1 \mathrm{M}$ glucose at $50 \mathrm{mV} \mathrm{s}^{-1}$

It is clearly seen that the highest mass activity for glucose oxidation under both anodic peaks A1 and $\mathbf{A 2}$ is shown by the AuNPs/ $\mathrm{C}_{\mathrm{MW}} / \mathrm{GC}$ catalyst followed by AuNPs/C $\mathrm{C}_{\text {ads }} / \mathrm{GC}$ and AuNPs/GC (Fig. 5). Notably, both carbon supported AuNPs catalysts significantly outperformed the pure AuNPs catalyst. Moreover, the mass activity under anodic peak A1 (Fig. 5a) is approximately 5.9 and 20.1 times higher at AuNPs/ $\mathrm{C}_{\text {ads }} / \mathrm{GC}$ and AuNPs/ $\mathrm{C}_{\mathrm{MW}} / \mathrm{GC}$, respectively, than that of AuNPs/GC, whereas the mass activity under anodic peak A2 (Fig. $5 \mathrm{~b}$ ) is approximately 1.5 and 2.2 times higher at AuNPs/C $\mathrm{C}_{\mathrm{ads}} / \mathrm{GC}$ and AuNPs/C $\mathrm{CW}_{\mathrm{MW}} / \mathrm{GC}$, respectively, as compared to that of the pure AuNPs/GC catalyst. These results demonstrate the improved 
electrocatalytic activity of the carbon supported AuNPs catalysts.

\section{CONCLUSIONS}

In summary, the oxidation of glucose was examined in an alkaline media using the carbon supported AuNPs nanocomposites prepared by two different approaches: chemical adsorption of AuNPs from the prepared citrate stabilized AuNP colloidal solution on the carbon powder surface and one-pot microwave-assisted synthesis. The electrocatalytic activity of those catalysts for the oxidation of glucose was compared with that of AuNPs prepared by the citrate reduction method. The electrocatalytic measurements demonstrate the enhanced electrocatalytic performance of the carbon supported Au nanoparticles for glucose oxidation, compared with that of the pure Au nanoparticles. The catalyst of the carbon supported $\mathrm{Au}$ nanoparticles prepared by microwaveassisted synthesis shows the highest activity for glucose electrooxidation.

Received 29 November 2018 Accepted 4 December 2018

\section{References}

1. H. N. Verma, P. Singh, R. M. Chavan, Vet. World, 7, 72 (2014).

2. P. Chandra, J. Singh, A. Singh, et al., J. Nanoparticles, 2013, 535901 (2013). DOI: 10.1155/2013/535901.

3. M. C. Daniel, D. Astruc, Chem. Rev., 104, 293 (2004).

4. Y. Zhou, C. Jin, Y. Li, et al., Nano Today, 20, 101 (2018).

5. G. J. Hutchings, J. K. Edwards, Front. Nanosci., 3, 249 (2012).

6. Y. D. Han, Y. M. Park, H. J. Chun, et al., Sens. Actuators, B, 220, 233 (2015).

7. P. Baptista, E. Pereira, P. Eaton, et al., Anal. Bioanal. Chem., 391, 943 (2008).

8. X. Huang, M. A. El-Sayed, J. Adv. Research, 1, 13 (2010).

9. N. Elahi, M. Kamali, M. H. Baghersad, Talanta, 184, 537 (2018).

10. G. Doria, B. Conde, L. Veigas, et al., Sensors, 12, 1657 (2012).

11. Y. Zhang, W. Chu, A. D. Foroushani, et al., Materials, 7, 5169 (2014).

12. K. E. Toghil, R. G. Compton, Int. J. Electrochem. Sci., 5, 1246 (2010).
13. S. Kerzenmacher, J. Ducree, R. Zengerle, et al., J. Power Sources, 182, 1 (2008).

14. D. Basu, S. Basu, J. Solid State Electrochem., 17, 2927 (2013).

15. A. Brouzgou, P. Tsiakaras, Top. Catal., 58, 1311 (2015). DOI: 10.1007/s11244-015-0499-1.

16. Y. B. Vassilyev, O. A. Khazova, N. N. Nikolaeva, J. Electroanal. Chem., 196, 127 (1985).

17. E. B. Makovos, C. C. Liu, Bioelectrochem. Bioenerg., 15, 157 (1986).

18. L. A. Larew, D. C. Johnson, J. Electroanal. Chem., 262, 167 (1989).

19. R. R. Adzic, M. W. Hsiao, E. B. Yeager, J. Electroanal. Chem., 260, 475 (1989).

20. M. W. Hsiao, R. R. Adzic, E. G. Yeager, J. Electrochem. Soc., 143, 759 (1996).

21. S. Ben Aoun, Z. Dursun, T. Koga, et al., J. Electroanal. Chem., 567, 175 (2004).

22. M. Tominaga, T. Shimazoe, M. Nagashima, et al., Electrochem. Commun., 7, 189 (2005).

23. J.-J. Yu, S. Lu, J. W. Li, et al., J. Solid State Electrochem., 11, 1211 (2007).

24. M. Pasta, F. L. Mantia, Y. Cui, Electrochim. Acta, 55, 5561 (2010).

25. Y. Hu, J. Jin, P. Wu, Electrochim. Acta, 56, 491 (2010).

26. L. Han, S. Zhang, L. Han, et al., Electrochim. Acta, 138, 109 (2014).

27. N. Arjona, G. Trejo, J. Ledesma-Garcia, et al., RSC Advances, 6, 15630 (2016).

28. G. C. Ferreira, T. W. Napporn, K. B. Kokoh, et al., J. Electrochem. Soc., 164, H603 (2017).

29. R. A. Escalona-Villalpando, M. P. Gurrola, G. Trejo, et al., J. Electroanal. Chem., 816, 92 (2018).

30. D. T. Nguyen, D.-J. Kim, M. Gi So, et al., Adv. Powder Technol., 21, 111 (2010).

31. S. K. Sivaraman, S. Kumar, V. Santhanam, J. Colloid Interface Sci., 361, 543 (2011).

32. P. Zhao, N. Li, D. Astruc, Coord. Chem. Rev., 257, 638 (2013).

33. E. Agunloye, A. Gavriilidis, L. Mazzei, Chem. Eng. Sci., 173, 275 (2017).

34. L. Shi, E. Buhler, F. Boue, et al., J. Colloid Interface Sci., 492, 191 (2017).

35. E. Agunloye, L. Panariello, A. Gavriilidis, Chem. Eng. Sci., 191, 318 (2018).

36. F. Takahashi, N. Yamamoto, M. Todoriki, et al., Talanta, 188, 651 (2018).

37. P. R. Teixeira, M. S. C. Santos, A. L. G. Silva, et al., Colloids Surf., B, 148, 317 (2016).

38. J. Zhou, J. Ralston, R. Sedev, et al., J. Colloid Interface Sci., 331, 251 (2009).

39. R. B. Hurtado, M. Cortez-Valadez, C. P. RamirezRodriguez, et al., Phys. Lett. A, 380, 2658 (2016).

40. M. Luty-Blocho, K. Fitzner, V. Hessel, et al., Chem. Eng. Sci., 171, 279 (2011).

41. K. Paclawski, B. Streszewski, W. Jaworski, et al., Colloids Surf., A, 413, 208 (2012). 
42. Z. Khan, T. Singh, J. I. Hussain, et al., Colloids Surf., $B$, 104, 11 (2013).

43. T. Maruyama, Y. Fujimoto, T. Maekawa, J. Colloid Interface Sci., 447, 254 (2015).

44. M. Chen, Y. He, X. Liu, et al., Powder Technol., 311, 25 (2017).

45. G. Frens, Nat. Phys. Sci., 241, 20 (1973).

46. S. Biggs, M. K. Chow, C. F. Zukoski, et al., J. Colloid Interface Sci., 160, 511 (1993).

47. J. Kimling, M. Maier, B. Okenve, et al., J. Phys. Chem. $B, 110,15700$ (2006).

48. J. Polte, T. T. Ahner, F. Delissen, et al., J. Am. Chem. Soc., 132, 1296 (2010).

49. H. Angerstein-Kozlowska, B. E. Conway, A. Hamelin, et al., Electrochim. Acta, 31, 1051 (1986).
Daina Upskuvienė, Aldona Balčiūnaitė, Jūratė Vaičiūnienė, Algirdas Selskis, Rimantas Vaitkus, Loreta Tamašauskaitè-Tamašiūnaitè, Eugenijus Norkus

Au NANODALELIŲ, PARUOŠTŲ SKIRTINGAIS METODAIS, ELEKTROKATALIZINIO AKTYVUMO GLIUKOZĖS ELEKTROOKSIDACIJAI PALYGINIMAS

Santrauka

Darbe aukso nanodalelès (AuNPs) buvo paruoštos taikant redukcijos citratu metodą. AuNPs-anglies nanokompozitai gauti pasitelkus du skirtingus metodus: cheminę Au nanodalelių adsorbciją ant anglies miltelių paviršiaus ir naudojant stabilizuotą $\mathrm{Au}$ nanodaleliụ koloidinị tirpalą bei mikrobangų sintezę. Gauti nanokompozitai buvo apibūdinti naudojant skenuojančiąją elektroninę mikroskopiją (SEM) ir indukuotos plazmos optinès emisijos spektroskopiją (ICP-OES), o jų elektrokatalizinis aktyvumas gliukozès oksidacijai šarminèje terpèje įvertintas naudojant ciklinę voltamperometriją.

Nustatyta, kad daug didesniu elektrokataliziniu aktyvumu gliukozès oksidacijos reakcijai šarminèje terpejje pasižymi Au nanodalelių-anglies nanokompozitai, palyginti su gryno Au nanodalelių katalizatoriumi. Geriausiomis elektrokatalizinèmis savybėmis pasižymejo katalizatorius, gautas Au nanodaleles nusodinant ant anglies pasitelkus mikrobangų sintezę. 
